\title{
Cultural Activity of the Tomsk Region Population
}

\author{
Sergey Romanchukov \\ Institute of Cybernetics \\ National Research Tomsk Polytechnic University, TPU \\ Tomsk, Russia \\ inoy@vtomske.ru \\ Taisiya Maklakova \\ Department of Economics \\ National Research Tomsk Polytechnic University \\ Tomsk, Russia \\ mclakova.t@gmail.com
}

\author{
Elena Berestneva \\ Institute of Cybernetics \\ National Research Tomsk Polytechnic University \\ Tomsk, Russia \\ berestneva_1@mail.ru \\ Sergey Shukharev \\ Institute of Cybernetics \\ National Research Tomsk Polytechnic University, TPU \\ Tomsk, Russia \\ shukharev.sergey@mail.ru \\ Oksana Zharkova \\ National Research Tomsk State University, TSU \\ Tomsk, Russia \\ osz@tpu.ru
}

\begin{abstract}
The cultural capital of the region's inhabitants is one of the significant resources in the regional innovation processes. Cultural activity is analyzed as an indicator of the cultural capital realization, while it refers to the frequency of individual visits to cultural institutions. The existing research practices in this field are conducted within the framework of the P. Bourdieu cultural capital concept and the theory of rational behavior. Finally, data on cultural activity in the city of Tomsk were analyzed in order to highlight dominant patterns in visits to cultural institutions by its residents on the basis of data obtained in the research in 2015-2016
\end{abstract}

Key words - cultural capital, cultural activity, innovative potential, innovation processes, modernization, socio-cultural transformation.

\section{INTRODUCTION}

The thesis of the correlation existence between the economic growth of the region and the characteristics of the social environment in particular, the level of tolerance and level of culture seems intuitively obvious, although its empirical justification seems a rather nontrivial matter. Researchers trying to apply the concept of "creative class" to Russian reality, are forced to point out that creativity in Russian society is still a potentially creative state, although they emphasize that the main task of modernization in Russia lies not in the technogenic sphere, but in the creation of modern society, modern structures and modern human, " and the creative class main should play the notorious role in this process" [1]. Socio-cultural transformation of society underlies modernization of the economy [2].

In this article we draw on the results of a study implemented within the framework of the project "Sociocultural Evolution of Russia and its Regions", launched in 2005 by the Institute of Philosophy of the Russian Academy of Sciences, in which one of the important indicators of the level of development of the region is the degree of cultural potential realization in this Region. The concept of "cultural potential" is close to the notion of creativity (although, of course, it is far from identical), in any case, it is a question of certain characteristics of social space and human capital becoming the basis for the information economy. In the methodology underlying this project, the level of the region inhabitants education, the degree and quality of information consumption from the media, the level of religiosity, interethnic and interreligious tolerance, entertainment establishments (see, for example: [3-5]) are mentioned as the empirical indicators of the cultural potential and its implementation in individual regions. Cultural capital and the level of cultural activity are not the same for the different region's population in Russia. We also proceed from the assumption that the level of cultural activity is indirectly related to the notorious "creativity" of the population and that it can be higher in more innovative regions of the country.

Factors determining the cultural activity of the population of the innovation region (with understanding of cultural activity as part of the cultural potential and capital of the actors of modernization processes) will be of special interest to us.

\section{CUltural ACTIVITY IN TOMSK REgION}

Cultural activity or, more precisely, cultural participation is usually defined as [7-12]:

1) frequency of visits to cultural events;

2) consumption of "cultural goods" through the media;

3) the practice of cultural activities, i.e. participation in cultural events as their creator, agent, etc.

In our study, cultural activity is important for considering it in the context of cultural capital, which characterizes the population of the region as participants in socio-cultural and socioeconomic modernization processes. 
The presence of statistical interrelations between the indicators characterizing the demographic characteristics of the respondents (gender, age, marital status, number of

The results are given in Table 1 and 2 for the male and female respondents separately. The tables show pairs of values, where the first number is the correlation coefficient, and the number in brackets is the significance level. Traditionally, in statistics, significance levels of 0.05 and 0.01 are considered as indicators of sufficient reliability (the probability that the judgment is erroneous), values greater than 0.05 indicate that it is impossible to reliably announce the existence of a correlation relationship, values less than 0,01 , on the contrary, speak of a reliable correlation.

Conventional designations: numbers represent correlation coefficients; Next in brackets are the levels of significance of these correlations; *** - high level of significance of correlations $(<0.01)$; $* *$ - the average level of correlation significance (0.05-0.01); * - Absence of significant correlation children), their assessment of their own social status and the frequency of visits to various cultural events was investigated using Spearman's rank correlation coefficients.

$(>0.05)$.

In all these tables, reliable correlations are identified by three asterisks. Only one asterisk indicates pairs of values that do not demonstrate a reliable relationship.

We can see that for the male population of the region there is no reliable correlation between the level of education and the form of leisure activities, at the same time, the social stratum and the level of prosperity directly affect most forms of leisure activities, as the number of children and marital status often limit the frequency of visits to clubs, discos and other entertainment. At the same time, more "cultural" forms of leisure do not show statistical interdependencies with these indicators (which, incidentally, can be explained by the rare frequency of visits to such events, in which the change in marital status hardly affects).

\section{TABLE 1. CORRELATION BETWEEN THE RESPONDENT'S SOCIO-DEMOGRAPHIC CHARACTERISTICS AND THE CULTURAL INSTITUTIONS ATTENDANCE (MALE)}

\begin{tabular}{|c|c|c|c|c|c|c|c|c|}
\hline & library & theater & circus & museum & stadium & $\begin{array}{l}\text { interest } \\
\text { club. }\end{array}$ & disco & cinema \\
\hline $\begin{array}{c}\text { Soc. layer } \\
\text { (RF) }\end{array}$ & $\begin{array}{c}0,128 \\
(0,02)^{* *}\end{array}$ & $0,137(0,01)^{* *}$ & $0,257(0,00)^{* * *}$ & $0,167(0,00)^{* * *}$ & $\begin{array}{c}0,201 \\
(0,00)^{* * *}\end{array}$ & $0,057_{*}(0,32)$ & $\begin{array}{c}0,176 \\
(0,00)^{* * *}\end{array}$ & $\begin{array}{c}0,255 \\
(0,00)^{* * *}\end{array}$ \\
\hline $\begin{array}{l}\text { Soc. layer } \\
\text { (town) }\end{array}$ & $0,054(0,33)^{*}$ & $0,112(0,04)^{* *}$ & $0,210(0,00)^{* * *}$ & $0,157(0,00)^{* * *}$ & $\begin{array}{c}0,195 \\
(0,00)^{* * *}\end{array}$ & $0,061(0,30)^{*}$ & $\begin{array}{c}0,196 \\
(0,00)^{* * *}\end{array}$ & $\begin{array}{c}0,216 \\
(0,00)^{* * *}\end{array}$ \\
\hline $\begin{array}{l}\text { S. layer } \\
\text { (region) }\end{array}$ & $0,104(0,08)^{*}$ & $0,146(0,01)^{* *}$ & $0,185(0,00)^{* * *}$ & $0,180(0,00)^{* * *}$ & $\begin{array}{c}0,146 \\
(0,01)^{* *}\end{array}$ & $\begin{array}{c}0,120 \\
(0,05)^{* *}\end{array}$ & $\begin{array}{c}0,128 \\
(0,03)^{* *}\end{array}$ & $\begin{array}{c}0,197 \\
(0,00)^{* * *}\end{array}$ \\
\hline Age & $0,088(0,11)^{*}$ & $0,096(0,08)^{*}$ & $0,127(0,03)^{* *}$ & $0,146(0,01)^{* * *}$ & $\begin{array}{c}0,363 \\
(0,00)^{* * * *}\end{array}$ & $\begin{array}{c}0,313 \\
(0,00)^{* * *}\end{array}$ & $\begin{array}{c}0,389 \\
(0,00)^{* * *}\end{array}$ & $\begin{array}{c}0,494 \\
(0,00)^{* * *}\end{array}$ \\
\hline Family & $-0,087(0,12)^{*}$ & $0,003(0,96)^{*}$ & $0,008(0,89)^{*}$ & $-0,065(0,24)^{*}$ & $\begin{array}{c}-0,176 \\
(0,00)^{* * * *}\end{array}$ & $\begin{array}{c}-0,186 \\
(0,00)^{* * *}\end{array}$ & $(0,00)^{-0,232}$ & $(0,00)^{-0 * 3 *}$ \\
\hline Children & $-0,079(0,15)^{*}$ & $-0,07(0,17)^{*}$ & $-0,013(0,82)^{*}$ & $\begin{array}{c}-0,155 \\
(0,00)^{* * *}\end{array}$ & $\begin{array}{c}-0,200 \\
(0,00)^{* * * *}\end{array}$ & $\begin{array}{c}-0,189 \\
(0,00)^{* * *}\end{array}$ & $\begin{array}{l}-0,230 \\
(0,00)^{* * *}\end{array}$ & $\begin{array}{c}-0,389 \\
(0,00)^{* * *}\end{array}$ \\
\hline Education & $0,095(0,08)^{*}$ & $0,056(0,30)^{*}$ & $-0,023(0,69)^{*}$ & $0,140(0,01)^{* *}$ & $0,071(0,18)^{*}$ & $0,054(0,35) x^{`}$ & $\begin{array}{l}-0,047 \\
(0,39)^{*}\end{array}$ & $0,037(0,47)^{*}$ \\
\hline
\end{tabular}

TABLE 2. CORRELATION BETWEEN THE SOCIO-DEMOGRAPHIC CHARACTERISTICS OF RESPONDENTS AND THE ATTENDANCE OF CULTURAL INSTITUTIONS (FEMALE)

\begin{tabular}{|c|c|c|c|c|c|c|c|c|}
\hline & library & theater & circus & museum & stadium & $\begin{array}{l}\text { interest } \\
\text { club. }\end{array}$ & disco & cinema \\
\hline Soc. layer (RF) & $\begin{array}{l}-0,096 \\
(0,06)^{*}\end{array}$ & $\begin{array}{l}0,050 \\
(0,35)^{*}\end{array}$ & $\begin{array}{l}-0,023 \\
(0,70)^{*}\end{array}$ & $0,083(0,13)^{*}$ & $\begin{array}{c}0,141 \\
(0,01)^{* *}\end{array}$ & $\begin{array}{c}0,174 \\
(0,00)^{* * *}\end{array}$ & $\begin{array}{c}0,165 \\
(0,00)^{* * *}\end{array}$ & $\begin{array}{c}0,190 \\
(0,00)^{* * *}\end{array}$ \\
\hline $\begin{array}{l}\text { Soc. layer } \\
\text { (town) }\end{array}$ & $-0,117(0,03)^{* *}$ & $0,039(0,47)^{*}$ & $\begin{array}{l}-0,018 \\
(0,77)^{*}\end{array}$ & $0,014(0,80)^{*}$ & $0,078(0,17)^{*}$ & $0,119(0,05)^{* *}$ & $\begin{array}{c}0,165 \\
(0,00)^{* * *}\end{array}$ & $\begin{array}{c}0,196 \\
(0,00)^{* * *}\end{array}$ \\
\hline $\begin{array}{l}\text { S. layer } \\
\text { (region) }\end{array}$ & $\begin{array}{ll}-0,196 \\
* * *\end{array}$ & $0,059(0,31)^{* *}$ & $\begin{array}{l}-0,079 \\
(0,22)^{*}\end{array}$ & $0,014(0,81)^{*}$ & $0,076(0,22)^{*}$ & $0,119(0,07)^{*}$ & $0,128(0,04)^{*}$ & $\begin{array}{c}0,182 \\
(0,00)^{* * *}\end{array}$ \\
\hline Age & $-0,125(0,02)^{* *}$ & $-0,01(0,84)^{*}$ & $0,064(0,27)^{*}$ & $0,112(0,04)^{* *}$ & $\begin{array}{c}0,367 \\
(0,00)^{* * *}\end{array}$ & $0,137(0,02)^{* *}$ & $\begin{array}{c}0,455 \\
(0,00)^{* * *}\end{array}$ & $\begin{array}{c}0,500 \\
(0,00)^{* * *}\end{array}$ \\
\hline Family & $-0,087(0,10)^{*}$ & $0,005(0,92)$ & $0,074(0,21)^{*}$ & $\begin{array}{c}-0,170 \\
(0,00)^{* * *}\end{array}$ & $\begin{array}{l}-0,132 \\
(0,02)^{* *}\end{array}$ & $-0,201(0,00)^{* * *}$ & $\begin{array}{c}-0,293 \\
(0,00)^{* * *}\end{array}$ & $\begin{array}{c}-0,161 \\
(0,00)^{* * *}\end{array}$ \\
\hline Children & $\begin{array}{l}0,027 \\
(0,60)^{*}\end{array}$ & $-0,04(0,42)^{*}$ & $0,134(0,02)^{* *}$ & $-0,040(0,45)^{*}$ & $-0,284(0,00)^{* * *}$ & $-0,053(0,37)^{*}$ & $-0,378(0,00)^{* * *}$ & $-0,427(0,00)^{* * *}$ \\
\hline Education & $-0,020(0,69)^{*}$ & $0,039(0,46)^{*}$ & $-0,018(0,77)^{*}$ & $0,082(0,13)^{*}$ & $0,031(0,58)^{*}$ & $0,061(0,30)^{*}$ & $0,033(0,57)^{*}$ & $0,170(0,00)^{* * *}$ \\
\hline
\end{tabular}


Women demonstrate much less dependence of their cultural preferences on external factors. As with men, the lack of children correlates with the greater frequency of entertainments [19]. It can be assumed that in both cases the children reduces their parent's opportunity to spend time organizing and conducting their own leisure. In terms of attendance of cultural institutions, such as theaters and museums, women show less correlations on their family and financial situation than men.

The second group (tables 3 and 4) reflects the correlation between the subjective social status of the respondents and their demographic characteristics. It is interesting that for male respondents the only characteristic that correlates reliably with all categories of the respondent's assessed status in the society is his age, whereas in women the interrelations between all indicators are traced. It should be noted a somewhat unusual behavior of the assessment of the "social situation in the region", which is less closely related to similar estimates for the country and the populated area, however, its behavior can be explained by the fact that this issue, being in fact the third one-type issue in a row, could cause irritation among respondents and became a record holder in the number of absences, refusals to respond and "protest" answers.

The third group of tables (5 and 6) is devoted to the interdependence between the frequency of various cultural event's attendance and demonstrates for both men and women the presence of a reliable correlation between the attendance of cultural events. Presumably, this can be explained by the fact that the most active respondents who live a full-fledged social life and have access to various parts of it actively and willingly attend a variety of activities, whereas respondents who do not have access to places of their holding, financial opportunity, free time or simply desire, do not participate in any forms of cultural events.

TABLE 3. CORRELATION BETWEEN SUBJECTIVE SOCIAL STATUS AND DEMOGRAPHIC CHARACTERISTICS (MALE)

\begin{tabular}{|c|c|c|c|c|c|c|c|}
\hline & $\begin{array}{l}\text { Soc. layer } \\
\text { (RF) }\end{array}$ & $\begin{array}{l}\text { Soc. layer } \\
\text { (town) }\end{array}$ & $\begin{array}{l}\text { Soc. layer } \\
\text { (region) }\end{array}$ & Age & Family & Children & Education \\
\hline S. layer (RF) & & $0,827(0,00)^{* * *}$ & $0,714(0,00)^{* * *}$ & $\begin{array}{c}0,218 \\
(0,00)^{* * *}\end{array}$ & $\begin{array}{l}0,096 \\
(0,04)^{* *}\end{array}$ & $\begin{array}{l}-0,074 \\
(0,11)^{*}\end{array}$ & $\begin{array}{l}0,069 \\
(0,13)^{*}\end{array}$ \\
\hline $\begin{array}{l}\text { S. Iayer } \\
\text { (town) }\end{array}$ & $0,827(0,00)^{* * *}$ & & $0,724(0,00)^{* * *}$ & $\begin{array}{l}0,182 \\
(0,00)^{* * * *}\end{array}$ & $\begin{array}{l}0,113 \\
(0,02)^{* *}\end{array}$ & $-0,036(0,43)^{*}$ & $\begin{array}{l}0,041 \\
(0,38)^{*}\end{array}$ \\
\hline $\begin{array}{l}\text { S. layer } \\
\text { (region) }\end{array}$ & $0,71(0,00)^{* * *}$ & $0,724(0,00)^{* * *}$ & & $\begin{array}{c}0,178 \\
(0,00 * * * *\end{array}$ & $0,058(0,25)^{*}$ & $-0,100(0,04)^{* *}$ & $0,129(0,01)^{* * *}$ \\
\hline
\end{tabular}

TABLE 4. CORRELATION BETWEEN SUBJECTIVE SOCIAL STATUS AND DEMOGRAPHIC CHARACTERISTICS (FEMALE)

\begin{tabular}{|l|c|c|c|c|c|c|c|}
\hline & $\begin{array}{c}\text { Soc. Iayer } \\
\text { (RF) }\end{array}$ & $\begin{array}{c}\text { Soc. layer } \\
\text { (town) }\end{array}$ & $\begin{array}{c}\text { Soc. Iayer } \\
\text { (region) }\end{array}$ & Age & Family & Children & Education \\
\hline S. layer (RF) & & $0,785(0,00)^{* * *}$ & $0,640(0,00)^{* * *}$ & $0,213(0,00)^{* * *}$ & $0,123(0,00)^{* * *}$ & $-0,168(0,00)^{* * *}$ & $0,147(0,00)^{* * *}$ \\
\hline $\begin{array}{l}\text { S.layer } \\
\text { (town) }\end{array}$ & $0,785(0,00)^{* * *}$ & & $0,666(0,00)^{* * *}$ & $0,222(0,00)^{* * *}$ & $0,157(0,00)^{* * *}$ & $.0,106(0,01)^{* *}$ & $0,159(0,00)^{* * *}$ \\
\hline $\begin{array}{l}\text { S.layer } \\
\text { (region) }\end{array}$ & $0,640(0,00)^{* * *}$ & $0,666(0,00)^{* * *}$ & & $0,227(0,00)^{* * *}$ & $0,197(0,00)^{* * *}$ & $-0,135(0,00)^{* * *}$ & $0,199(0,00)^{* * *}$ \\
\hline
\end{tabular}

TABLE 5. CORRELATION BETWEEN THE VISIT'S FREQUENCY FOR VARIOUS CULTURAL EVENTS (MALE)

\begin{tabular}{|c|c|c|c|c|c|c|c|c|}
\hline & library & theater & circus & museum & stadium & $\begin{array}{c}\text { interest } \\
\text { club. }\end{array}$ & disco & cinema \\
\hline library & & $\begin{array}{c}0,496(0,00) \\
* * * \\
\end{array}$ & $\begin{array}{c}0,321 \\
(0,00) * * *\end{array}$ & $\begin{array}{c}0,423 \\
(0,00)^{* * *}\end{array}$ & $\begin{array}{c}0,235 \\
* * * \\
\end{array}$ & $\begin{array}{c}0,189(0,00) \\
* * * * \\
\end{array}$ & $\begin{array}{c}0,210 \\
(0,00)^{* * *} \\
\end{array}$ & $\begin{array}{c}0,215(0,00) \\
* * * \\
\end{array}$ \\
\hline theater & $\begin{array}{c}0,496 \\
(0,00) * * *\end{array}$ & & $\underset{* * * *}{0,338}(0,00)$ & $0,555(0,00)$ & $0,313(0,00)$ & $\begin{array}{l}0130 \\
(003) * *\end{array}$ & $0,184_{* * *}(0,00)$ & $\begin{array}{c}0,318 \\
(0,00) * * *\end{array}$ \\
\hline circus & $\begin{array}{l}0,321 \\
(0,00) \\
* * *\end{array}$ & $\begin{array}{c}0,338(0,00) \\
* * * *\end{array}$ & & $0,412(0,00)$ & $0,192(0,00)$ & $0,189(0,00)$ & $\begin{array}{c}0,312 \\
(0,00) * * *\end{array}$ & $\begin{array}{c}0,276 \\
(0,00) * * *\end{array}$ \\
\hline museum & $\begin{array}{l}0,423 \\
(0,00) \\
* * *\end{array}$ & $0,555(0,00)$ & $0,412(0,00)$ & & $0,347(0,00)$ & $0,293(0,00)$ & $0,229(0,00)$ & $0,402(0,00)$ \\
\hline stadium & $\begin{array}{l}0,235 \\
(0,00) \\
* * *\end{array}$ & $0,314(0,00)$ & $0,192(0,00)$ & $\begin{array}{c}0,347(0,00) \\
* *\end{array}$ & & $0,427(0,00)$ & $0,55 \underset{* * *}{6}(0,00)$ & $\underset{* * *}{0,497(0,00)}$ \\
\hline $\begin{array}{l}\text { interest } \\
\text { club }\end{array}$ & $\begin{array}{c}0,189 \\
(0,002) \\
(* * *)\end{array}$ & $0,130(0,031)$ & $\underset{* * *}{0,190(0,00)}$ & $\underset{* * * *}{0,293(0,00)}$ & $\underset{* * *}{0,427(0,00)}$ & & $0,402 \underset{* * *}{2}(0,00)$ & $0,354(0,00)$ \\
\hline disco & $\begin{array}{c}0,210 \\
(0,000)^{* *}\end{array}$ & $0,184(0,00)$ & $0,313(0,00)$ & $\underset{* * *}{0,229}(0,00)$ & $\begin{array}{c}0,556 \\
(0,00)^{* * *}\end{array}$ & $0,402(0,00)$ & & $\begin{array}{c}0,545 \\
(0,00)^{* * *}\end{array}$ \\
\hline cinema & $\begin{array}{c}0,215 \\
(0,000) * *\end{array}$ & $\begin{array}{c}0,318(0,00) \\
* *\end{array}$ & $\begin{array}{c}0,276(0,00) \\
* * * \\
\end{array}$ & $\begin{array}{c}0,402(0,00) \\
* * *\end{array}$ & $\begin{array}{c}0,497 \\
(0,00) * * *\end{array}$ & $\begin{array}{c}0,354(0,00) \\
* * * *\end{array}$ & $\begin{array}{c}0,545 \\
(0,00) * * *\end{array}$ & \\
\hline
\end{tabular}


TABLE 6. CORRELATION BETWEEN THE VISIT'S FREQUENCY FOR VARIOUS CULTURAL EVENTS (FEMALE)

\begin{tabular}{|c|c|c|c|c|c|c|c|c|}
\hline & library & theater & circus & museum & stadium & $\begin{array}{l}\text { interest } \\
\text { club. }\end{array}$ & disco & cinema \\
\hline library & & $\begin{array}{l}0,234 \\
(0,00) \\
* * *\end{array}$ & $\begin{array}{l}0,124 \\
(0,05) \\
* * *\end{array}$ & $\begin{array}{l}0,277 \\
(0,00) \\
* * *\end{array}$ & $\begin{array}{l}0,355 \\
(0,00) \\
* * *\end{array}$ & $\begin{array}{l}0,326 \\
(0,00) \\
* * *\end{array}$ & $0,254(0,00)$ & $0,075 *(0,18)$ \\
\hline theater & $\underset{* * *}{0,234}(0,00)$ & & & $0,263(0,00)$ & $\begin{array}{l}0,360 \\
(0,00) \\
* * *\end{array}$ & $\begin{array}{l}0,167 \\
\left(\begin{array}{l}0,00) \\
* * *\end{array}\right.\end{array}$ & $\begin{array}{l}0,181 \\
(0,00) \\
* * *\end{array}$ & $\begin{array}{l}0,270 \\
(0,00) \\
* * * *\end{array}$ \\
\hline circus & $0,124(0,05)$ & $\begin{array}{l}0,263 \\
(0,00) \\
* * *\end{array}$ & & $\begin{array}{l}0,325 \\
(0,00) \\
* * *\end{array}$ & $\begin{array}{l}0,172 \\
(0,00) \\
* * *\end{array}$ & $\begin{array}{l}0,209 \\
(0,00) \\
* * *\end{array}$ & $\begin{array}{l}0,178 \\
(0,01) \\
* * *\end{array}$ & $0,265(0,00)$ \\
\hline museum & $\underset{* * *}{0,277}(0,00)$ & $\begin{array}{l}0,360 \\
(0,00) \\
* * *\end{array}$ & $\underset{* * *}{0,328}(0,00)$ & & & $0,341(0,00)$ & $\begin{array}{l}0,370 \\
\left(\begin{array}{l}0,00) \\
* * *\end{array}\right.\end{array}$ & $\begin{array}{l}0,256 \\
(0,00) \\
* * *\end{array}$ \\
\hline stadium & $\underset{* * *}{0,355}(0,00)$ & $\begin{array}{l}0,167 \\
(0,00) \\
* * *\end{array}$ & $\begin{array}{l}0,172 \\
(0,00) \\
* * *\end{array}$ & $\begin{array}{l}0,341 \\
(0,00) \\
* * *\end{array}$ & & $\begin{array}{l}0,453 \\
(0,00) \\
* * *\end{array}$ & $\begin{array}{c}0474 \\
(0,00) \\
* * *\end{array}$ & $\underset{* * *}{0,457}(0,00)$ \\
\hline $\begin{array}{l}\text { interest } \\
\text { club }\end{array}$ & $\underset{* * *}{0,326(0,00)}$ & $\begin{array}{l}0,181 \\
(0,00) \\
* * *\end{array}$ & $\underset{* * *}{0,209}(0,00)$ & $\begin{array}{l}0,370 \\
(0,00) \\
* * *\end{array}$ & $\begin{array}{l}0,453 \\
(0,00) \\
* * *\end{array}$ & & & $\underset{* * * *}{0,465(0,00)}$ \\
\hline disco & $\underset{* * *}{0,254}(0,00)$ & $\begin{array}{l}0,270 \\
(0,00) \\
* * *\end{array}$ & $0,178(0,01)$ & $\begin{array}{l}0,256 \\
(0,00) \\
* * *\end{array}$ & $\begin{array}{l}0,474 \\
(0,00) \\
* * * *\end{array}$ & $\begin{array}{c}0,465 \\
(0,00)^{* * *}\end{array}$ & & $0,460(0,00)$ \\
\hline cinema & $\begin{array}{c}0,077(0,18) \\
*\end{array}$ & $\begin{array}{l}0,199 \\
(0,00) \\
* * *\end{array}$ & $\underset{* * *}{0,265(0,00)}$ & $\begin{array}{c}0,323 \\
(0,00)^{* * *}\end{array}$ & $\begin{array}{l}0,457 \\
(0,00) \\
* * *\end{array}$ & $\begin{array}{l}0,306 \\
(0,00) \\
* * *\end{array}$ & $\begin{array}{c}0,460(0,00) \\
* * *\end{array}$ & \\
\hline
\end{tabular}

\section{CONCLUSION}

1. Active visitors of "cultural entertainment" (and, as noted above, those who actively attend "mass culture institutions" as discotheque, stadium, cinema), also visit more "cultural institutions" (museum, theater, libraries).

2. A group of less active "family respondents" - with the advent of the spouse and children, cultural activity is reduced in terms of visits to the disco clubs, stadiums and cinemas, as well as, in part, the museum - in this respect, the results of our study coincide with the results of the European studies that were described above. One of the most obvious reasons is that a disco and a theater are the places where people go to meet friends or to show their relationship. The establishment of a family in Russia means, as a rule, the birth of children (to a greater extent than in Europe), the family status negatively affects the entertainment: the incentive and/or the opportunities (economic, temporary, etc.) reduces when a child borns.

3 . The group of the respondents inactive in terms of cultural activities, including a high percentage of people below average status and people of age over the 60 years. It should be noted that people over the age of 60 as a whole actually stop their cultural activity (it decreases noticeably after 45-59 years), except that elderly men and women visit libraries, often enough, while some women continue to go to theaters and museums.

With regard to education, the lack of a statistical relationship between cultural activity and education is somewhat surprising, but may be partly explained by the following points: firstly, it can be assumed that the cultural activity of people with higher education is not fixed by the options for answers of our questionnaire - in particular, It has already been noted, it does not include, for example, the option of visiting concert and / or organ halls or other types of specific cultural events, so that an additional clarification on the cultural activity of people with higher education (and separately - related to the sphere of education) requires a more detailed investigation. Secondly, it is likely that the education factor as such is really not determinative for the isolation of culturally active groups in Russia and an important role is played by economic status (which does not correlate with the level of education directly in Russia). This may indicate that in Russia, at least in Siberia, the "cultural elite", which P. Bourdieu wrote about in his works, is actually missing is a social stratum that could be considered as "forming culture" and setting cultural samples that are adopted by other social groups (such as, for example, according to M. Sokolov, the capital's intelligentsia in the Soviet Union [9]).

So, in Tomsk there is a rather high attendance of cultural institutions in comparison with other regions, which indirectly confirms the existence of a certain connection between the innovativeness of the region and the indicator such as cultural activity. At the same time, as the data of our research show, high cultural activity is more characteristic of the young part of the population, more adults, families and elderly sharply reduce the attendance of cultural institutions, including theaters and museums. The educational factor is not determinative, and there is no positive correlation between educational level and cultural activity in both men and women.

Thus, the cultural potential in Tomsk appears to be more pronounced in the student environment; The group of more culturally active people over 30 was not singled out. It should be noted that the range of available cultural institutions is significantly narrowed by the city/village criterion, therefore the contribution to the cultural capital of the region is still made 
mainly by the urban population of Tomsk, in which innovative resources for modernization are concentrated.

On the one hand, these observations indicate that there really is a population layer in Tomsk that demonstrates a certain cultural potential, but, on the other hand, it lacks of formed "cultural elite", possessing cultural capital (along with educational), which should be a stable resource for innovative development of the region (or it just weakly manifests itself according to the criterion of cultural activity in the given questionnaire format).

\section{ACKNOWLEDGMENT}

The research was conducted in Tomsk Polytechnic University with financial support from Ministry of Education and Science of the Russian Federation in line with accomplishing the research scientific work on "Evaluation and improvement of social, economic and emotional welfare of elderly people", contract № 14.Z50.31.0029.

\section{REFERENCES}

[1] Barbashin, M.Yu., Barkov, F.A, Serikov, A.V. \& Khachetsukov, Z.M. (2014) Sotsial'noe znachenie kreativnogo klassa v rossiyskom sotsiume [The social significance of the creative class in Russian society]. Gumanitarnyy ezhegodnik. 13. pp. 234-241.

[2] Lapin, N.I. (2009) Territorial'nye soobshchestva i obshchnosti: rost sotsiokul'turnogo potentsala i ego disbalansy [Local communities and communion: The growth of social and cultural potential and its imbalances]. In: Lapin, N.I. \& Belyaeva, L.A. (eds) Regiony Rossii: sotsiokul'turnye portrety regionov $\mathrm{v}$ obshcherossiyskom kontekste [Russian Regions: Socio-cultural portraits of the regions in the national context]. Moscow: Academia. pp. 688.

[3] Nemirovsky, V.G. \& Nemirovskaya, A.V. (2012) Dinamika sotsiokul'turnykh protsessov $\mathrm{v}$ Krasnoyarskom krae (na materialakh sotsiologicheskikh issledovaniy $\mathrm{v}$ regione $\mathrm{v} 2010$ 2012 gg.) [The dynamics of social and cultural processes in Krasnoyarsk Region (sociological studies in the region in 20102012.)]. Krasnoyarsk: Siberian Federal University.

[4] Shekova, E.L. (2002) Marketingovoe issledovanie rynka kul'turnykh uslug v Rossii i za rubezhom [Marketing research of cultural services market in Russia and abroad]. Marketing v Rossi i za rubezhom.

[5] Interfax Agency. (2015) Poseshchaemost' rossiyskikh teatrov v proshlom godu vyrosla na $17 \%$ [The attendance of Russian theaters increased by $17 \%$ last year]. [Online] Available from: www.interfax.ru/russia/425320.

[6] Radaev, V.V. (2003) Ponyatie kapitala, formy kapitalov i ikh konvertatsiya [The concept of capital, forms of capital and their conversion]. [Online] Available from: http://ecsocman.hse.ru/ons/msg/105221.html.

[7] Ateca-Amestoy, V. (2008) Determining heterogeneous behavior for theater attendance. Journal of Cultural Economics. V.32(2), pp. 127-151. DOI: $10.1007 / \mathrm{s} 10824-008-9065-\mathrm{z}$

[8] Bouder-Pailler, D. (1999) A Model for Measuring the Goals of Theatre Attendance. International Journal of Arts Management. Vol.1(2), pp. 4-15.
[9] Sokolov, M. (2013) Kul'turnyy kapital: pochemu lyubiteli opery zarabatyvayut bol'she lyubiteley pop-muzyki? [The cultural capital: Why opera fans make more than lovers of pop music?]. [Online] Available from: https://postnauka.ru/longreads/ 9644 .

[10] Werner, G. (2004) Cultural Capital and Social Inequality in the Life Course. European Sociological Review. 20(4). pp. 333-344. DOI: $10.1093 /$ esr $/$ jch028

[11] Sullivan, A. (2001) Cultural Capital and Educational Attainment. Sociology. 35(4). pp. 893-912. DOI: 10.1177/0038038501035004006

[12] Katsillis, J. \& Rubinson, R. (1990) Cultural Capital, Student Achievement, and Educational Reproduction: The Case of Greece. American Sociological Review. 55(2). pp. 270-279.

[13] Montgomery, S. \& Robinson, M. (2010) Empirical evidence of the effects of marriage on male and female attendance at sports and arts. Social Science Quarterly. 91(1), pp. 99-116. DOI: 10.1111/j.1540-6237.2010.00683.x

[14] Bygren, L.O., Konlaan, B.B. \& Johansson, S.E. (1996) Attendance at cultural events, reading books or periodicals, and making music or singing in a choir as determinants for survival: Swedish interview survey of living conditions. British Medical Journal. 313. pp. 1577-1580. DOI: http://dx.doi.org/10.1136/bmj.313.7072.1577

[15] Cuypers, K., Krokstad, S., Holmen, T.L., SkjeiKnudtsen, M., Bygren, L.O. \& Holmen, J. (2012) Patterns of receptive and creative cultural activities and their association with perceived health, anxiety, depression and satisfaction with life among adults: the HUNT study, Norway. Journal of Epidemiology and Community Health. 66(8). pp. 698-703.

[16] Kasinsky, S.V., Dyrko, N.P., Laskeeva, N.I. \& Lapteva, I.A. (eds) (2015) Tomskaya oblast' $v$ tsifrakh [Tomsk region in figures]. Tomsk: Tomskstat.

[17] Russian Federation Government. (2015) Rasporyazhenie Pravitel'stva Rossiyskoy Federatsii ot 14 yanvarya 2015 g. 022 Kontseptsiya sozdaniya $\mathrm{v}$ Tomskoy oblasti innovatsionnogo territorial'nogo tsentra "INO Tomsk" [Order v 22 of the Russian Federation Government of January 14, 2015, The concept of the Territorial Innovation Center "INO Tomsk" in Tomsk Region].

[18] Romashkin, G.F. \& Davydenko, V.A. (eds) Sotsiokul'turnaya dinamika - portret Tyumenskoy oblasti [The socio-cultural dynamics - A portrait of Tyumen Region]. Tyumen: Tyumen State University.

[19] Ivankina L. I. , Berestneva O. G., Shelekhov I. L. View of young people of the modern Russian society on predominant values of partnership in marriage (on the basis of survey) // Procedia - Social and Behavioral Sciences. - 2015, vol. 166, pp. 2-6. 